\title{
ANALIZA ANTROPOLOGICZNA SZCZĄTKÓW KOSTNYCH POCHODZĄCYCH Z GROBU SKRZYNKOWEGO KULTURY POMORSKIEJ ZE STANOWISKA NR 1 W KRECIESZKACH, GM. BEDLNO, POW. KUTNO, WOJ. LÓDZKIE
}

SŁOWA KLUCzowe: kultura pomorska, urny, badania antropologiczne, ludzkie kości Keywords: Pomerianian culture, urns, grave anthropological research, human bones

Cmentarzysko w Kręcieszkach, stan. 1 odkrył miejscowy rolnik Jan Olejniczak w trakcie prac polowych w 1985 r. Znalezisko w postaci jednej popielnicy zostało zgłoszone do Muzeum Regionalnego w Kutnie.

Stanowisko położone jest około $15 \mathrm{~km}$ od Kutna, w gminie Bedlno przy drodze krajowej nr 2 (w kierunku Warszawy) na piaszczystym, słabo widocznym wzniesieniu (ryc. 1). Obszar cmentarzyska leży na Równinie Kutnowskiej, przynależnej do Niziny Środkowomazowieckiej (Kondracki 1981: 316-318). Obecnie jest to obszar całkowicie objęty uprawami rolnymi, jednakże z informacji uzyskanych od miejscowej ludności teren, przynajmniej w części cmentarzyska był zalesiony. To prawdopodobnie przyczyniło się do stosunkowo późnego jego odkrycia. Właśnie skutkiem intensyfikacji prac rolnych w 1985 r. naruszono jeden z grobów. Podczas dwóch sezonów badań $(1987,1988)$ znaleziono trzy groby skrzynkowe kultury pomorskiej datowane na okres halsztacki D. W latach 2005-2007 przeprowadzono kolejne badania wykopaliskowe na tym stanowisku. Ich wynikiem było odkrycie reliktów osady kultury łużyckiej z IV okresu epoki brązu, trzech grobów podkoszowych kultury pomorskiej datowanych na okres lateński A oraz reliktu budynku z okresu wpływów rzymskich, zlokalizowanego na terenie przypuszczalnej osady.

Wyniki badań są w trakcie opracowywania i sukcesywnie publikowane. Znaleziska z pierwszych dwóch sezonów badawczych, z lat osiemdziesiątych 
XX w., zostały opublikowane w Eódzkich Sprawozdaniach Archeologicznych (Rychter, Stasiak 2006-2007). Kolejnym etapem było przedstawienie zagadnień związanych z konstrukcją budynku pochodzącego z okresu wpływów rzymskich (Rychter 2010).

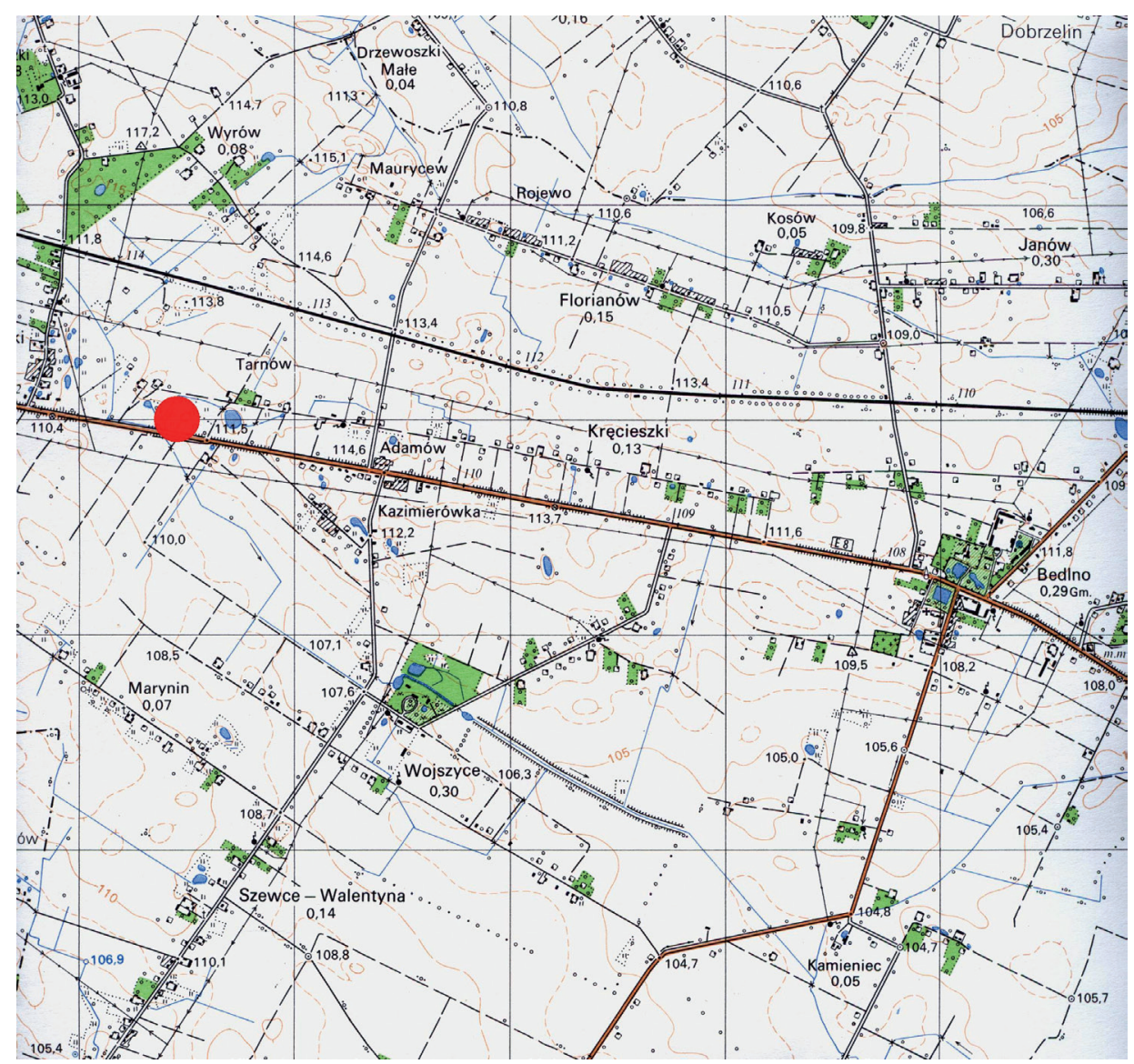

Ryc. 1. Lokalizacja stanowiska (oprac. M. Rychter).

Naszym celem jest przedstawienie wyników badań antropologicznych szczątków kostnych pochodzących z popielnic z grobu skrzynkowego nr 1 kultury pomorskiej (ryc. 2), który został odkryty w roku 1987. Był to jedyny niezniszczony grób tego typu na omawianym stanowisku. Znajdowało się w nim 36 dużych naczyń, w tym 23 typowe, określane jako urny. Szczątki kostne zachowały się tylko w 21 naczyniach (ryc. 3).

Popielnice eksplorował Mariusz Rychter. Osady piasku, które zalegały w górnej części naczyń nie były brane pod uwagę, a właściwa eksploracja, z podziałem na warstwy dotyczyła tylko poziomu z zachowanymi kośćmi. Stara- 
no się dzielić wypełnisko na trzy warstwy. Nie zawsze to było możliwe, jak w przypadku naczyń małych czy też z niewielką ilością kości.

Celem ekspertyzy antropologicznej było ustalenie:

- ilości osobników w pochówku;

- płci i wieku zgonu pochowanych osobników;

- przyżyciowej wysokości ciała;

- schorzeń dających obraz na kośćcu;

- występowania przepalonych kości zwierzęcych wśród szczątków ludzkich.

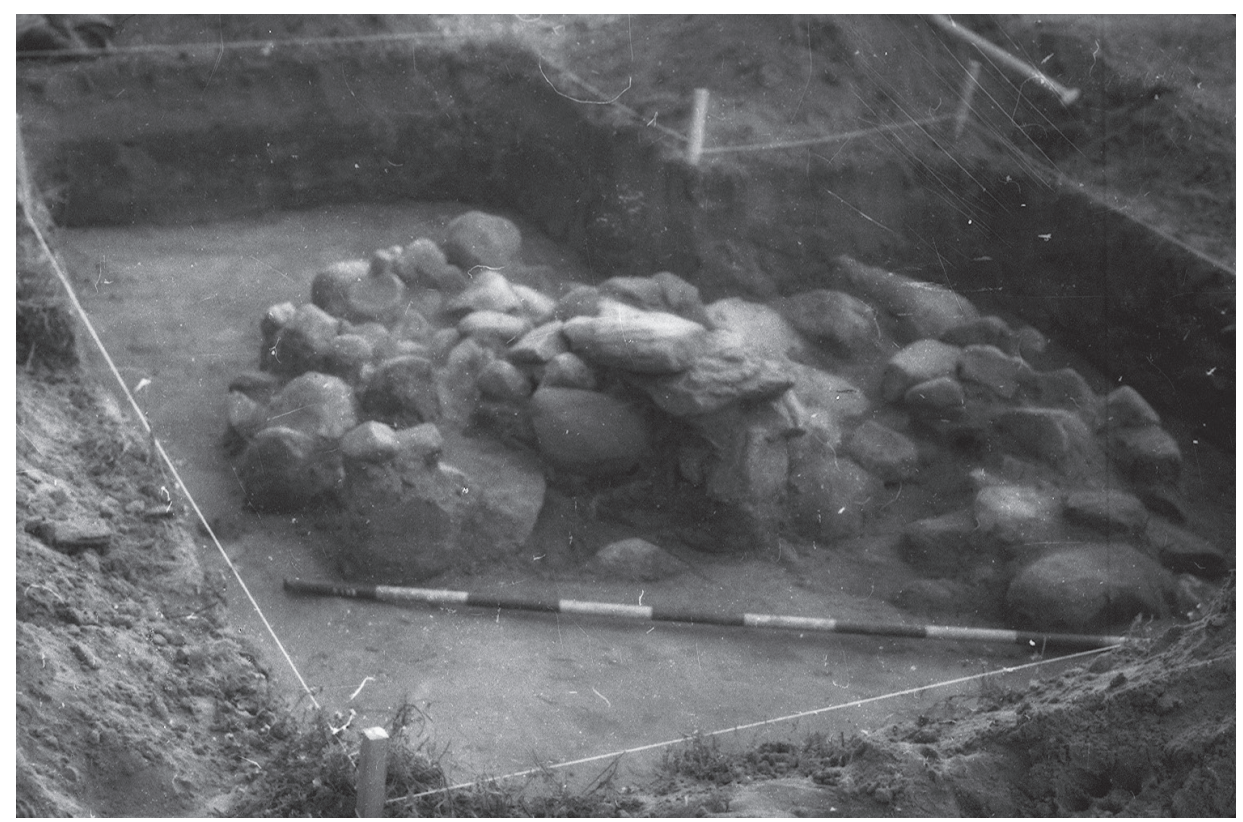

Ryc. 2. Grób nr 1. Faza odsłaniania płaszcza kamiennego

(fot. archiwum Muzeum Regionalnego w Kutnie).

Określenia płci zmarłych dokonano przy uwzględnieniu ogólnej masywności fragmentów kostnych oraz dymorfizmu płciowego w ukształtowaniu morfologicznym cech czaszki i szkieletu postkranialnego (Strzałko i in. 1974; Strzałko, Henneberg 1975).

Wiek zgonów oznaczono biorąc pod uwagę stopień obliteracji głównych szwów czaszkowych, abrazję zębów oraz nasilenie zmian inwolucyjnych kośćca (Malinowski, Strzałko 1985; Malinowski, Wolański 1988).

Analizując materiał podjęto także próbę odtworzenia przybliżonej przyżyciowej wysokości ciała na podstawie fragmentów przepalonych kości (Malinowski, Strzałko 1985; Malinowski, Wolański 1988).

Badania antropologiczne objęły również obserwacje w zakresie schorzeń dających obraz na kośćcu w oparciu o ich podział zaproponowany przez Judytę 
Gładykowską-Rzeczycką (1976; 1989). W opisie uwzględniono barwę, stopień przepalenia i rozdrobnienia materiału kostnego, zwrócono też uwagę na ewentualne zabarwienie kości solami miedzi.

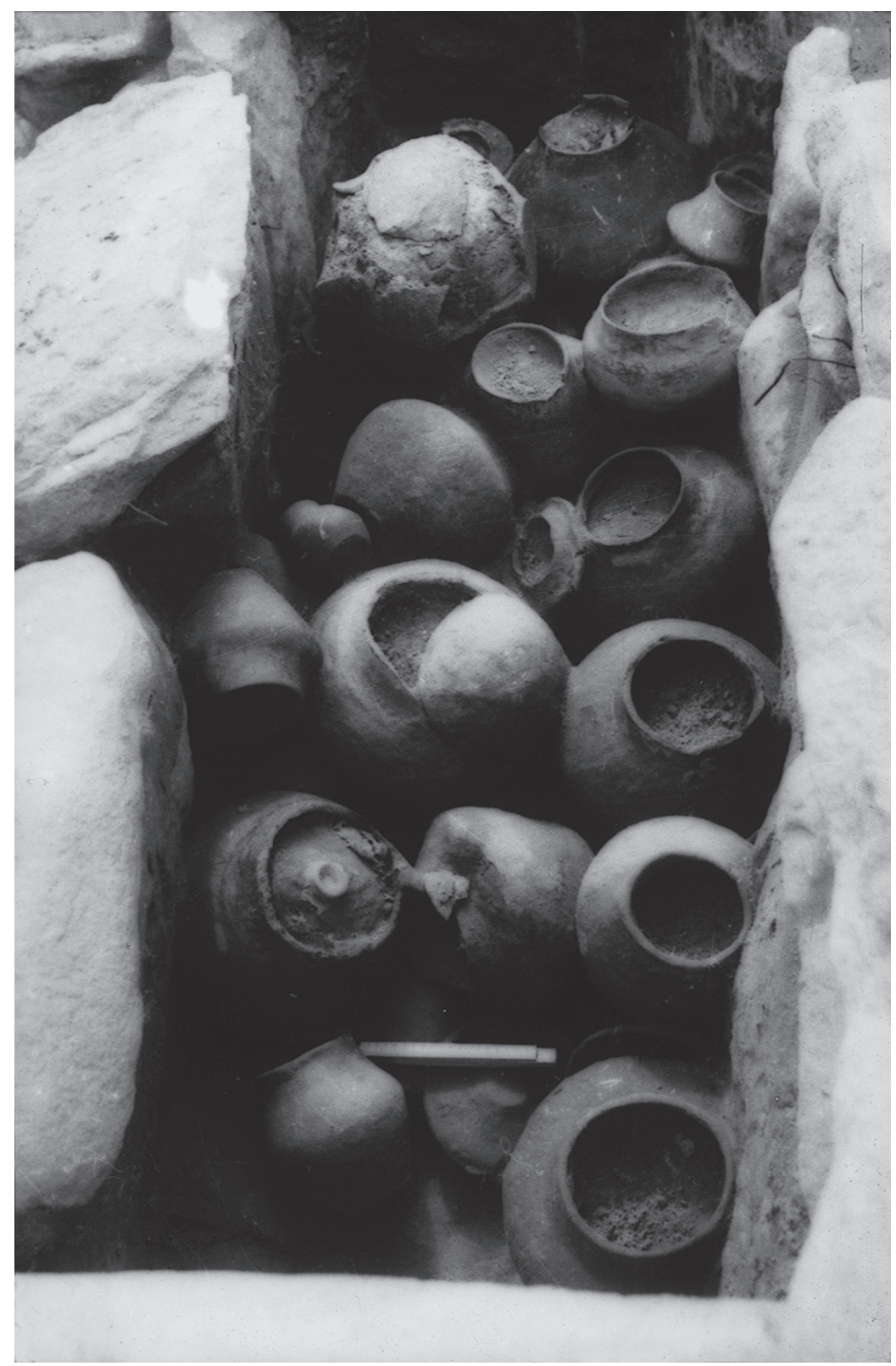

Ryc. 3. Grób nr 1. Otwarta komora grobowa z popielnicami in situ (fot. archiwum Muzeum Regionalnego w Kutnie). 
ANTROPOLOGICZNY OPIS SZCZĄTKóW KOSTNYCH ZNAJDUJĄCYCH SIĘ W POPIELNICACH W GROBIE NR 1

\section{Popielnica 3}

Popielnicę eksplorowano w trzech warstwach (od dołu I, II, III).

Najwięcej fragmentów kości czaszki znajdowało się w warstwie trzeciej, mniej (oraz mniejszych) w II, zaś niewielka ilość drobnych fragmentów w najniższej. Szczątki szkieletu postkranialnego dość równomiernie rozmieszczone były w trzech warstwach.

W grobie znajdowały się szczątki kostne mężczyzny(?) zmarłego w przedziale wiekowym 21-35 lat (adultus). Kości zostały przepalone w stopniu średnim, charakteryzują się średnim rozdrobnieniem, zabarwieniem jasnoszarym (w kilku miejscach widoczne są niewielkie ślady patyny).

Ciężar szczątków: $515 \mathrm{~g}$ (I w-wa), 645g (II w-wa), $840 \mathrm{~g}$ (III w-wa) $=2000 \mathrm{~g}$. Wysokość ciała: około 161-165 cm.

Zachowały się liczne fragmenty reprezentujące prawie wszystkie regiony szkieletu. Na podstawie ich morfologii można stwierdzić, że kościec mężczyzny charakteryzował się dość masywną budową.

Czaszka: odnotowano liczne fragmenty kości sklepienia czaszki, wśród których były fragmenty z ostro ząbkowanymi i otwartymi odcinkami szwów czaszkowych (strzałkowego i węgłowego), fragmenty kości skroniowych oraz klinowej. Zaobserwowano również wyrostek czołowy lewej kości jarzmowej, dwa fragmenty wyrostków zębodołowych kości szczękowych, fragment żuchwy oraz zęby: $2 \mathrm{~J}_{1}, 2 \mathrm{~J}_{2}$, korzeń $\mathrm{J}, \mathrm{C}$ szczęki, $\mathrm{P}_{1}, \mathrm{P}_{2}, 2$ korzenie $\mathrm{P}$ oraz dwa korzenie nieokreślonych zębów stałych ${ }^{1}$.

Z kości szkieletu postkranialnego rozpoznano liczne fragmenty żeber, fragment łuku pierwszego kręgu szyjnego, ząb drugiego kręgu szyjnego, 4 dalszych kręgów szyjnych, 4 piersiowych oraz fragmenty nieokreślonych kręgów.

Z kości kończyn górnych rozpoznano fragmenty obojczyków, łopatek, fragmenty głów, trzonów oraz dwóch bliższych nasad kości ramiennych, nasad bliższych i trzonów kości łokciowych oraz promieniowych, drobne fragmenty kości śródręcza, 6 fragmentów paliczków.

$\mathrm{Z}$ kości kończyn dolnych odnotowano fragmenty kości miednicznych (średnica około $40 \mathrm{~mm}$ ) oraz 5 fragmentów trzonów, 2 ułamki nasad dalszych kości udowych, fragment rzepki, 2 ułamki nasad bliższych oraz 3 trzonów kości piszczelowych, fragmenty trzonu kości strzałkowej oraz fragmenty kości pochodzące z obu stóp.

Zmian patologicznych nie zaobserwowano.

\footnotetext{
${ }^{1} \mathrm{~J}$ - siekacze, $\mathrm{C}$ - kły, $\mathrm{P}$ - przedtrzonowe, $\mathrm{M}$ - trzonowe.
} 


\section{Popielnica 4}

Szczątki kostne dziecka, zmarłego w wieku infans I (zgon okołoporodowy).

Barwa kości głównie kremowa, miejscami szara i ciemnoszara, rozdrobnienie bardzo silne, przepalenie kości nierównomierne (głównie silne, miejscami słabe), o wadze $38 \mathrm{~g}$.

Zachowane drobne fragmenty kości sklepienia czaszki oraz piramida lewej kości skroniowej, bardzo drobne fragmenty zawiązków zębów mlecznych oraz korona mlecznego zęba trzonowego.

Szkielet postkranialny: mała ilość drobnych fragmentów głównie trzonów i nasad nieokreślonych kości długich.

Nie odnotowano zmian patologicznych ani pourazowych.

\section{Popielnica 6}

Popielnicę eksplorowano trzema warstwami (od dołu I, II, III).

Najwięcej fragmentów kości czaszki znajdowało się w warstwie trzeciej, mniej (oraz mniejszych) w II, zaś niewielka ilość drobnych fragmentów w najniższej. Szczątki szkieletu postkranialnego równomiernie rozmieszczone w trzech warstwach.

W grobie odnotowano szczątki kostne prawdopodobnie kobiety(?) zmarłej w wieku adultus/maturus (30-40 lat). Kości zostały przepalone w stopniu średnim, charakteryzują się średnim rozdrobnieniem, zabarwieniem jasnoszarym, miejscami ciemnoszarym (w kilku miejscach na trzonach kości długich punktowe zabarwienie tlenkami metali).

Ciężar szczątków: 370 g (I w-wa), 560 g (II w-wa), 580 g (III w-wa) = $=1510 \mathrm{~g}$.

Zachowały się liczne fragmenty reprezentujące prawie wszystkie rejony kośćca (średnia masywność kośćca).

Czaszka: zachowane ułamki kości ciemieniowych (grubość 3,5-5 mm), czołowej, potylicznej. Podstawowe szwy czaszkowe: wieńcowy (s. coronalis) - obliteracja odcinka C3, szew strzałkowy (sutura sagittalis) - zachowany fragment z obliterowanym odcinkiem S2 $\left(2^{0}-3^{0}\right)$, szew węgłowy ( $s$. lambdoidea $)$ - nieobliterowany. Z kości twarzoczaszki wyróżniono wyrostek czołowy prawej kości jarzmowej, fragmenty kości szczękowej oraz żuchwy (korzenie zębów od $\mathrm{J}_{1}$ do $\mathrm{M}_{3}$ ), zęby: 3C, 3M, 2P, część korzenia zęba siekacza.

Ze szkieletu postkranialnego rozpoznano liczne fragmenty żeber, a także kręgów szyjnych, 11 ułamków kręgów piersiowych oraz 4 lędźwiowych.

W grupie kości kończyn górnych zaobserwowano 2 fragmenty pochodzące z głów i 4 trzonów obu kości ramiennych, trzonów i nasad kości przedramienia oraz kości śródręcza i 2 odłamki paliczków.

Z kości kończyn dolnych rozpoznano fragmenty kości miednicznych, obu rzepek, fragmenty głów (średnica prawej około $37 \mathrm{~mm}$ ) oraz 7 fragmentów 
trzonów, 3 ułamki nasad dalszych kości udowych, fragmenty trzonów kości piszczelowych, trzonu kości strzałkowej, a także ułamki kości stóp.

Zmiany patologiczne:

- schorzenia aparatu żucia: ślad po próchnicy korony zęba $\mathrm{M}_{2}$ szczęki oraz prawego $\mathrm{M}_{3}$ żuchwy (ryc. 4) - ślad po ropniu przykorzeniowym pierwszego przedtrzonowca szczęki prawej;

- znaczna osteofitoza widoczna na trzonach kręgów lędźwiowych (wyrośla kostne - zmiana degeneracyjno-przeciążeniowa) (ryc. 5).

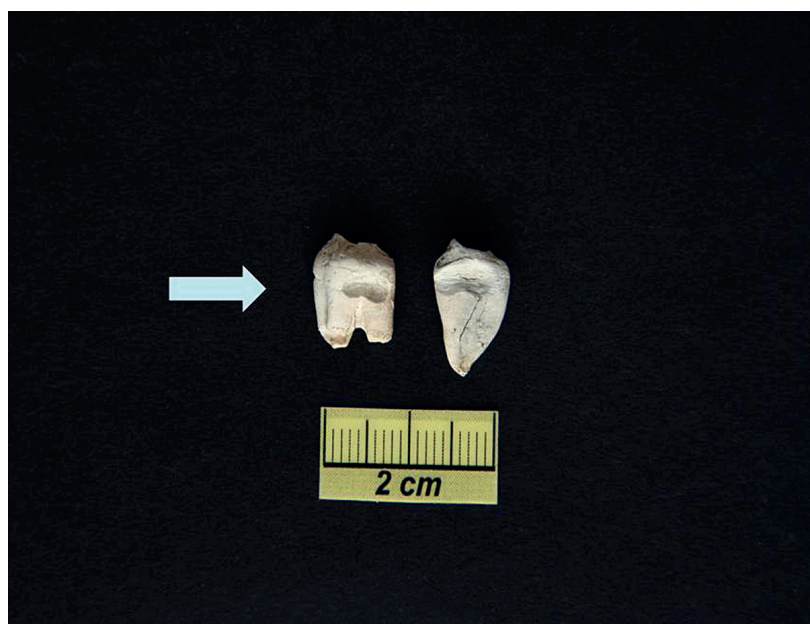

Ryc. 4. Grób nr 1. Popielnica nr 6. Ogniska próchnicy na zębach trzonowych żuchwy (fot. B. Borowska-Strugińska).

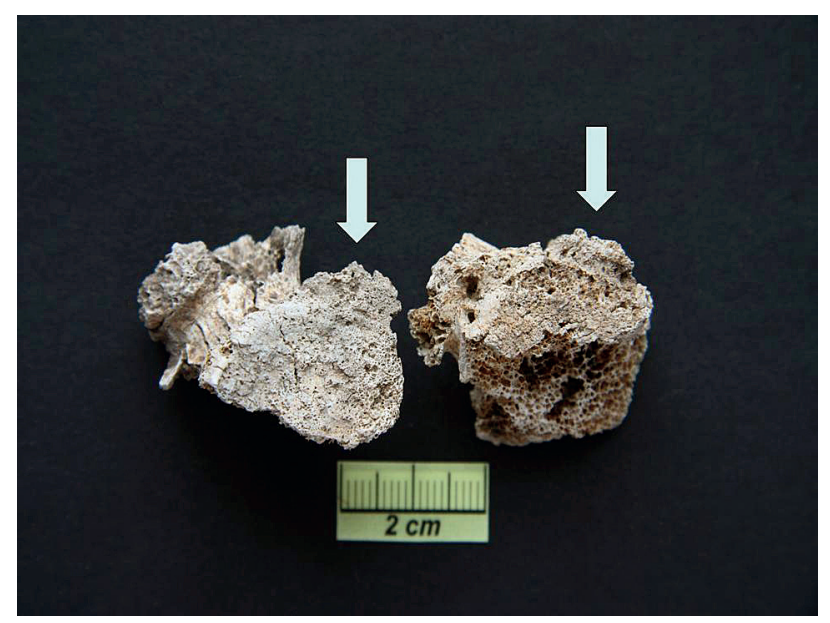

Ryc. 5. Grób nr 1. Popielnica nr 6. Osteofity na trzonach kręgów lędźwiowych (fot. B. Borowska-Strugińska). 


\section{Popielnica 7}

Materiał kostny niejednorodny, eksplorowany dwoma warstwami (I dolna, II górna).

Nie odnotowano różnic w składzie warstw.

Szczątki kostne pochodzące ze szkieletu dziecka, zmarłego w wieku infans I (zgon okołoporodowy).

Barwa kości głównie kremowa, miejscami szara, rozdrobnienie bardzo silne, przepalenie kości silne.

Ciężar szczątków: $17 \mathrm{~g}$ (I w-wa), $15 \mathrm{~g}$ (II w-wa) $=32 \mathrm{~g}$.

Zachowane drobne fragmenty kości sklepienia czaszki oraz piramida prawej kości skroniowej, zęby: 2 zawiązki mlecznych siekaczy oraz mlecznego trzonowca. Szkielet postkranialny: mała ilość drobnych ułamków głównie kości długich, wyróżniono m.in. 5 fragmentów trzonów żeber, 2 drobne ułamki trzonów kości udowych.

Nie odnotowano zmian patologicznych ani pourazowych.

\section{Popielnica 9}

Popielnicę eksplorowano trzema warstwami (od dołu I, II, III).

Szczątki kostne osobnika dorosłego (kobieta?), zmarłego w wieku adultus (20-25 lat).

Kości przepalone w stopniu średnim do słabego, charakteryzują się zabarwieniem jasnoszarym bądź ciemnoszarym, średnim rozdrobnieniem.

Ciężar szczątków: $750 \mathrm{~g}$ (I w-wa), $830 \mathrm{~g}$ (II w-wa), $660 \mathrm{~g}$ (III w-wa) $=2240 \mathrm{~g}$.

Wysokość ciała: około 160-164 cm.

Najwięcej fragmentów kości czaszki znajdowało się w warstwie najwyższej, mniej (oraz mniejszych) w II, zaś niewielka ilość drobnych ułamków kostnych w warstwie górnej.

Fragmenty szkieletu postkranialnego rozłożone były równomiernie w warstwach.

Czaszka: kilkadziesiąt małych fragmentów pochodzących z kości sklepienia czaszki, podstawowe szwy czaszkowe: wieńcowy (s. coronalis) - odcinek C1, C3 - nieobliterowane, szew strzałkowy (sutura sagittalis) - zachowany fragment z obliterowanym odcinkiem S3 $\left(2^{\circ}\right)$, szew węgłowy (s. lambdoidea) - nieobliterowany. Odnotowano niewielkie ułamki kości skroniowych, ułamek trzonu kości klinowej, fragmenty kości szczękowej oraz żuchwy. Zęby: 2J żuchwy, 2P żuchwy, C żuchwy z koroną, P żuchwy, 2M, 4 korzenie nieokreślonych zębów.

Szkielet postkranialny: fragmenty I i II kręgu szyjnego oraz trzony 4 dalszych kręgów szyjnych, 10 ułamków trzonów kręgów piersiowych, 5 fragmentów trzonów kręgów lędźwiowych, poza tym 4 ułamki trzonów nieokreślonych kręgów, 15 ułamków kości żeber, fragmenty nasad oraz trzonów kości ramien- 
nych, nasady bliższej lewej kości łokciowej i trzonu prawej łokciowej, ułamki trzonów kości promieniowych, 2 kości nadgarstka (trójgraniasta, wielokątna większa), 4 kości śródręcza oraz fragmenty 5 palców.

Z kości kończyny dolnej wyróżniono fragmenty kości miednicznych (biodrowych, lewej kulszowej), ułamki nasad i trzonów kości udowych, rzepek oraz kości podudzia i stóp (prawej skokowej, piętowej, sześciennej, klinowatych, śródstopia oraz paliczka).

Zmiany patologiczne:

- słaba poroza kości sklepienia czaszki (prawdopodobnie ślad po stanie zapalnym) (ryc. 6).

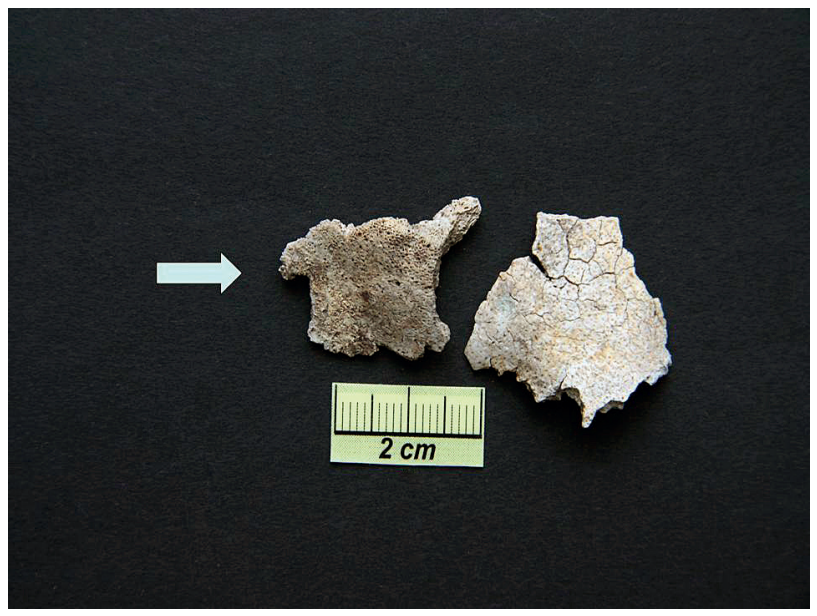

Ryc. 6. Grób nr 1. Popielnica nr 9. Poroza kości ciemieniowych (fot. B. Borowska-Strugińska).

\section{Popielnica 10}

Popielnicę eksplorowano trzema warstwami (od dołu I, II, III).

Najwięcej fragmentów kości czaszki znajdowało się w warstwie trzeciej (górnej), mniej w II, zaś niewielka ilość drobnych ułamków kostnych w warstwie najniższej. Przeważającą liczbę dużych fragmentów kręgów zawierała warstwa II, w I było kilkanaście drobnych ułamków kręgów. W warstwie I zarejestrowano największe fragmenty trzonów kości długich oraz duży fragment części bliższej lewej kości udowej, mniej licznie odnotowano fragmenty pochodzące z obu stóp (najwięcej ich było w warstwie II).

$\mathrm{W}$ grobie znajdowały się szczątki kostne mężczyzny, zmarłego w wieku adultus/maturus (30-45 lat). Kości zostały przepalone w stopniu średnim, charakteryzują się średnim rozdrobnieniem, barwą od kremowej do ciemnoszarej (ślady związków metali - seledynowe, rdzawe oraz drobne fragmenty stopionego żelaza wtopione w kości). 
Ciężar szczątków: $855 \mathrm{~g}$ (I w-wa), 1365 g (II w-wa), $765 \mathrm{~g}$ (III w-wa) = $2985 \mathrm{~g}$. Wysokość ciała: około $170 \mathrm{~cm}$.

Zachowały się liczne fragmenty reprezentujące prawie wszystkie części szkieletu (duża masywność).

Czaszka: rozpoznano ułamki kości mózgoczaszki. Podstawowe szwy czaszkowe: wieńcowy (s. coronalis) - obliteracja odcinka $\mathrm{C} 1\left(1^{0}\right), \mathrm{C} 2$ nieobliterowany, szew strzałkowy (sutura sagittalis) - zachowany fragment z obliterowanym odcinkiem S1, S2 $\left(2^{0}\right)$, szew węgłowy (s. lambdoidea) - nieobliterowany. Zachowane fragmenty $\mathrm{z}$ wyrostów sutkowatych kości skroniowych charakteryzuje duża masywność i wielkość. Z kości twarzoczaszki wyróżniono wyrostek czołowy lewej kości jarzmowej, fragmenty kości szczękowej oraz trzonu i obu gałęzi żuchwy. Zęby: korzenie zębów żuchwy z $2 \mathrm{~J}_{1}, 2 \mathrm{C}, 2 \mathrm{P}_{1}$, $2 \mathrm{P}_{2}$, szczęki $2 \mathrm{C}, 2 \mathrm{P}_{1}, 2 \mathrm{P}_{2}$, część korzenia kła oraz drobne fragmenty korzeni zębów trzonowych. Pośród kości szkieletu postkranialnego rozpoznano liczne fragmenty żeber, kręgów szyjnych 6 piersiowych oraz 5 lędźwiowych, 2 krzyżowych i guzicznej.

W grupie kości kończyn górnych zaobserwowano fragmenty łopatek, 3 fragmenty głów oraz 3 trzonów obu kości ramiennych, fragment części dalszej kości łokciowej ułamki kości promieniowych, nadgarstka (księżycowatej, łódeczkowatej), 3 kości śródręcza i 8 palców.

Z kości kończyn dolnych rozpoznano ułamki obu kości biodrowych i kulszowych, nasady bliższej lewej kości udowej, fragmenty trzonów kości udowych, piszczelowych oraz strzałki, ułamki kości stóp (skokowej, piętowej, sześciennej, łódkowatych, klinowatej oraz 5 fragmentów kości śródstopia).

Nie odnotowano zmian patologicznych.

\section{Popielnica 11}

Materiał kostny jednorodny, eksplorowany dwoma warstwami (I dolna, II górna).

Warstwa II zawierała głównie kości czaszki, jak również część kości długich.

W grobie znajdowały się szczątki kostne kobiety, zmarłej w wieku adultus/ maturus (30-45 lat). Kości charakteryzowało przepalenie w stopniu średnim, średnie rozdrobnienie oraz barwa ciemnoszara bądź szara.

Ciężar szczątków: 675 g (I w-wa), 817 g (II w-wa) = 1492 g.

Czaszka: zachowane kości mózgoczaszki (ciemieniowej, potylicznej, klinowej), fragment trzonu i prawej gałęzi żuchwy, prawej kości szczękowej i klinowej. Podstawowe szwy czaszkowe: szew strzałkowy (sutura sagittalis) - zachowany niewielki fragment nieobliterowany, szew węgłowy (s. lambdoidea) - L2 nieobliterowany. Zęby: korzenie 25 zębów w tym 3 trzonowych.

Pośród kości szkieletu postkranialnego rozpoznano liczne fragmenty żeber, łuku pierwszego kręgu szyjnego, trzon kręgu piersiowego, ułamki trzonów i na- 
sad dalszych kości ramiennych, nasad górnych i trzonów kości promieniowych, fragmenty trzonów łokciowych oraz 14 palców.

Z kości kończyn dolnych (głównie z warstwy I) zarejestrowano fragmenty trzonów kości udowych oraz nasady dalszej i głowy prawej udowej, ułamki kości stóp oraz drobne ułamki trzonów kości długich.

Nie odnotowano zmian patologicznych.

\section{Popielnica 13}

Materiał kostny jednorodny, eksplorowany dwoma warstwami (I dolna, II górna).

Kości czaszki odnotowane były głównie w warstwie II (jedynie fragment kości skroniowej znajdował się w warstwie I). Materiał kostny był przemieszany, gdyż w warstwie II zarejestrowano również fragmenty kręgów, kości miednicznych, kości długich oraz stóp (w warstwie I głównie trzony kości długich). Na kościach czaszki widoczne drobne niebiesko-zielone zabarwienia.

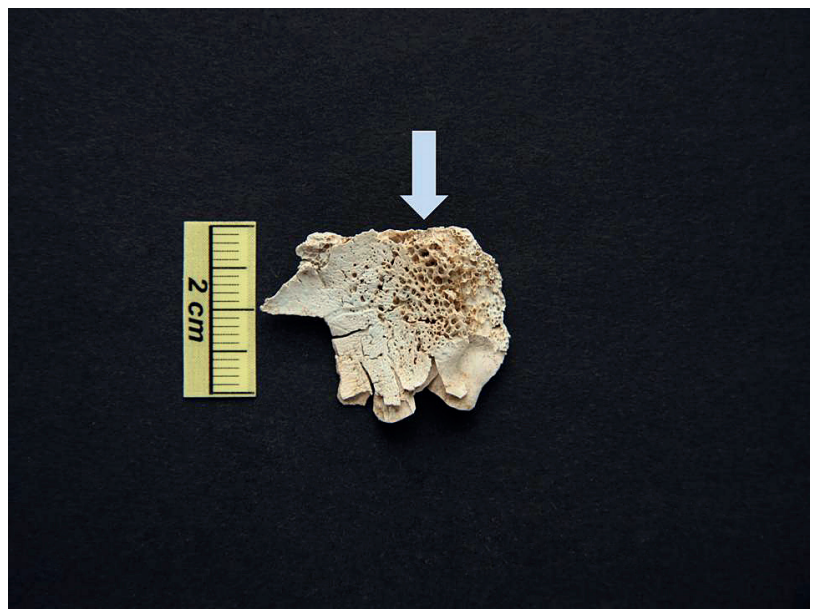

Ryc. 7. Grób nr 1. Popielnica nr 13. Cribra orbitalia

(fot. B. Borowska-Strugińska).

Szczątki kostne dziecka zmarłego w wieku infans II (około 12-14 lat).

Barwa przepalenia kości jasnokremowa do szarej, rozdrobnienie średnie, przepalenie średnie.

Ciężar szczątków: $305 \mathrm{~g}$ (I w-wa), 565 g (II w-wa), 135 g (II w-wa ze stropu) $=1005 \mathrm{~g}$.

Czaszka: kilka drobnych fragmentów kości sklepienia czaszki (ciemieniowej, potylicznej, czołowej), piramidy kości skroniowych, fragment kości klinowej, 2 ułamki kości szczękowych oraz gałęzi żuchwy. Zachowane odcinki szwów strzałkowego i węgłowego nieobliterowane. Zęby: korzeń C (długość 
wskazuje na około 12-14 lat), 2 korony zębów $\mathrm{M}_{3}$, drobne fragmenty koron zębowych.

Szkielet postkranialny: łuki siedmiu kręgów szyjnych, fragmenty trzonów kręgów piersiowych i 3 lędźwiowych, ułamki żeber, ułamek lewego obojczyka, prawej łopatki, fragmenty nasad bliższych kości ramiennych, trzonu kości przedramiennej, koniec bliższy prawej kości udowej (nasady nieprzyrośnięte), głowy oraz nasada dalsza kości udowych, 3 fragmenty trzonów kości piszczelowych, rzepka prawa, ułamki paliczków oraz kości skokowej i piętowej, ułamki paliczków.

Zmiany patologiczne:

- cribra orbitalia w stropie oczodołu (zmiany przerostowe w prawym stropie oczodołu. Zmiana ta powstaje w przypadku niedoboru żelaza w organizmie i jest oznaką anemii. Powoduje ona przerost istoty gąbczastej kości) (ryc. 7).

\section{Popielnica 14}

Szczątki kostne dziecka, zmarłego w wieku infans I (około 4 lat).

Barwa kości kremowa do szarej, rozdrobnienie bardzo silne, przepalenie silne.

Ciężar szczątków: $134 \mathrm{~g}$.

Materiał kostny zachowany bardzo słabo, odnotowano drobne ułamki kości mózgoczaszki, piramidy kości skroniowych, fragment lewego oczodołu, kości szczękowych oraz prawej gałęzi żuchwy, ułamki łuków kręgów oraz żeber, 1 ułamek trzonu kości udowej(?). Zęby mleczne: 2 kły, korony 4 trzonowców, 3 korzenie siekaczy (wskazują na około 4 lata) oraz drobne fragmenty koron zębowych.

Zmiany patologiczne:

- cribra orbitalia na sklepieniu lewego oczodołu.

\section{Popielnica 15}

Materiał kostny jednorodny, eksplorowany dwoma warstwami (I dolna, II górna).

Nie stwierdzono różnic w składzie warstw.

Szczątki kostne dziecka, zmarłego w wieku infans I (zgon okołoporodowy).

Barwa przepalenia kości kremowa do szarej, rozdrobnienie bardzo silne, przepalenie silne (miejscami średnie).

Ciężar szczątków: $22 \mathrm{~g}$ (I w-wa), $20 \mathrm{~g}$ (II w-wa) $=42 \mathrm{~g}$.

Czaszka: kilka drobnych fragmentów kości pochodzących z okolicy sklepienia czaszki oraz fragmenty piramid obu kości skroniowych.

Szkielet postkranialny: mała ilość, głównie bardzo drobnych ułamków trzonów i nasad kości długich, 5 fragmentów żeber, trzonu kości ramiennej, 2 części trzonów kości udowych.

Nie odnotowano zmian patologicznych. 


\section{Popielnica 16}

Szczątki kostne dziecka (płód?).

Zachowana szczątkowa ilość materiału kostnego, silnie rozdrobnione ułamki kostne.

Ciężar szczątków: $0,7 \mathrm{~g}$.

\section{Popielnica 19}

Materiał kostny jednorodny, eksplorowany dwoma warstwami (I dolna, II górna).

Najwięcej fragmentów kości czaszki odnotowano w warstwie II, mniej w warstwie I (podstawa kości potylicznej, kość jarzmowa).

W grobie znajdowały się szczątki kostne kobiety, zmarłej w wieku adultus (30-35 lat). Kości przepalone w stopniu średnim, charakteryzują się średnim rozdrobnieniem, barwą od kremowej do ciemnoszarej (ślady związków metali - seledynowe, rdzawe).

Ciężar szczątków: $715 \mathrm{~g}$ (I w-wa), $968 \mathrm{~g}$ (II w-wa) = $1683 \mathrm{~g}$.

Wysokość ciała: około $165 \mathrm{~cm}$.

Zachowały się liczne fragmenty reprezentujące prawie wszystkie części szkieletu.

Czaszka: odnotowano ułamki kości mózgoczaszki (potyliczna, ciemieniowe, czołowa), fragment trzonu oraz lewej gałęzi żuchwy, kość jarzmowa. Podstawowe szwy czaszkowe: wieńcowy (s. coronalis) - nieobliterowany, szew strzałkowy (sutura sagittalis) - zachowany fragment z obliterowanym odcinkiem S3 $\left(1^{\circ}\right)$, szew węgłowy (s. lambdoidea) - L1, L2 nieobliterowany. Zęby: korzenie zębów J, C, 4P, 2M żuchwy oraz drobne fragmenty korzeni zębów nieokreślonych.

Pośród kości szkieletu postkranialnego rozpoznano ułamki pierwszego i drugiego kręgu szyjnego oraz łuki trzech dalszych szyjnych, 2 trzony piersiowych, 3 ułamki kręgów lędźwiowych. Odnotowano 11 większych fragmentów kości żeber, część wyrostka barkowego łopatki oraz dwóch wydrążeń stawowych barkowych. Z kości obu kończyn górnych rozpoznano nasady dalsze kości ramiennych, fragmenty trzonów kości przedramienia, 2 kości nadgarstka (łódeczkowata, księżycowata), ułamki palców.

Z kości kończyn dolnych wyróżniono części kości miednicznych (w tym prawą panewkę stawu biodrowego i prawą kość kulszową), fragmenty trzonów i nasad dalszych kości udowych, drobne ułamki trzonów kości piszczelowych i paliczków.

Nie odnotowano zmian patologicznych. 


\section{Popielnica 21}

Szczątki kostne dziecka zmarłego w kategorii wiekowej infans I (prawdopodobnie płód).

Ciężar szczątków: $6 \mathrm{~g}$.

Zachowane tylko bardzo drobne fragmenty kości mózgoczaszki, ułamki kostne łuków i trzonów kręgów oraz trzon kości długiej (długość 3,5cm).

\section{Popielnica 24}

Szczątki kostne dziecka, zmarłego w przedziale wiekowym infans I (około 3-4 lat)

Materiał kostny jednorodny, eksplorowany trzema warstwami (od dołu I, II, III).

Ciężar szczątków: 64 g (I w-wa), 52 g (II w-wa), 14 g (III w-wa)=130 g.

Nie stwierdzono dużych różnic w składzie warstw. Barwa przepalonych kości od kremowej do szarej, rozdrobnienie bardzo silne, przepalenie silne (miejscami średnie).

Warstwa III - drobne ułamki kości mózgoczaszki;

Warstwa II - 3 fragmenty kości czaszki, lewego obojczyka oraz trzonu kości długiej;

Warstwa I - część trzonu żuchwy (bez zębów), bardzo drobne ułamki kości czaszki, fragmenty trzonów kości udowych i piszczelowych, drobne części trzonów kości długich. Zęby mleczne: korony 6 trzonowców (guzki nie starte), drobne fragmenty koron pochodzących z kłów i siekaczy.

Nie odnotowano zmian patologicznych.

\section{Popielnica 25}

Materiał kostny jednorodny, eksplorowany dwoma warstwami (I dolna, II górna).

Warstwa II zawierała większość kości czaszki (tylko piramida kości skroniowej znajdowała się w warstwie I), choć odnotowano również kości kończyn dolnych i górnych.

Szczątki kostne dziecka, zmarłego w wieku infans II (około 12 lat).

Barwa przepalenia kości jasnoszara do ciemnoszarej, rozdrobnienie silne, stopień przepalenia dość silny.

Ciężar szczątków: $153 \mathrm{~g}$ (I w-wa), $302 \mathrm{~g}$ (II w-wa)=455 g.

Czaszka: kilka drobnych fragmentów kości sklepienia czaszki (szwy nieobliterowane), część prawego oczodołu, piramidy kości skroniowych, 2 ułamki kości szczękowych. Zęby: stałe J, 2P, 2M oraz fragment korony i korzenia C (ukształtowany na około 12 lat).

Szkielet postkranialny: mała ilość, głównie bardzo drobnych ułamków trzonów kości długich, fragmenty końców bliższych oraz nasad dalszych kości udo- 
wych, talerza biodrowego kości miednicznej, głowa kości ramiennej, fragmenty trzonów kości piszczelowych, łuków kręgów, żeber oraz paliczków.

Nie odnotowano zmian patologicznych.

\section{Popielnica 26}

Materiał kostny jednorodny, eksplorowany trzema warstwami (od dołu I, II, III).

W warstwie III zgrupowane były głównie kości mózgoczaszki.

W popielnicy znajdowały się szczątki kostne mężczyzny, zmarłego w wieku maturus (30-55 lat). Kości zostały przepalone w stopniu średnim, charakteryzują się średnim rozdrobnieniem, barwą szaro-kremową.

Ciężar szczątków: 270 g (I w-wa), 678g + 640 g (II w-wa), 415 g + 352 g $($ III w-wa $)=2355 \mathrm{~g}$.

Wysokość ciała: około $175 \mathrm{~cm}$.

Zachowały się liczne fragmenty reprezentujące prawie wszystkie rejony kośćca (duża masywność).

Czaszka: rozpoznano ułamki kości pochodzące z mózgoczaszki, kości skroniowych i kości twarzoczaszki: szczęki oraz gałęzi żuchwy (niewielka ilość części kości czaszki szczególnie z odcinków przyszwowych, zachowany jedynie fragment szwu węgłowego nieobliterowany). Zęby: korzenie 4 kłów, 4 przedtrzonowych, 2 trzonowych i 2 siekaczy.

Z kości szkieletu postkranialnego rozpoznano drobne ułamki żeber, trzony 4 kręgów lędźwiowych i piersiowych.

W grupie kości kończyn górnych wyróżniono fragmenty nasad dalszych kości ramiennych, trzonów i nasad bliższych kości promieniowych, ułamki dwóch kości nadgarstka, 12 ułamków paliczków.

Z kości kończyn dolnych odnotowano fragmenty obu kości miednicznych, nasad górnych i dolnych oraz trzonów kości udowych, nasad dalszych oraz trzonów kości piszczelowych, rzepek, prawą kość piętową i lewą skokową, ułamki kości stępu i paliczków.

Nie stwierdzono zmian patologicznych.

\section{Popielnica 27}

Szczątki kostne silnie rozdrobnione, płeć i wiek nieokreślone.

Ciężar szczątków: $5 \mathrm{~g}$.

Zachowane niewielkie fragmenty kości mózgoczaszki, 2 fragmenty trzonów kości długich, 4 ułamki kostne.

\section{Popielnica 28}

Szczątki kostne dziecka, zmarłego w wieku infans I (około 5-6 lat).

Barwa kości jasnokremowa, rozdrobnienie bardzo silne.

Ciężar szczątków: $325 \mathrm{~g}$. 
Czaszka: zachowane jedynie fragmenty kości mózgoczaszki, piramid kości skroniowych, fragment szczęki i prawej gałęzi żuchwy, fragment lewego oczodołu. Zęby (zawiązki zębów stałych z częściowo uformowanymi korzeniami): $\mathrm{J}_{1}$ szczęki lewej, $\mathrm{J}_{2}$, C szczęki prawej, 4P szczęki, 4P żuchwy, korona $\mathrm{M}_{2}$, ułamki koron zębowych C i J żuchwy.

Szkielet pozaczaszkowy: drobne ułamki żeber, 5 fragmentów trzonów kręgów, głowa kości ramiennej, część trzonu prawej kości udowej, koniec bliższy lewej udowej, fragmenty trzonów kości piszczelowych, nasady dalsze kości udowych, głowa prawej udowej, ułamki kości strzałkowych.

Nie odnotowano zmian patologicznych.

\section{Popielnica 34}

Szczątki kostne dziecka, zmarłego w przedziale wiekowym infans I (około 6-9 miesięcy).

Ciężar szczątków: $37 \mathrm{~g}$.

Materiał kostny silnie rozdrobniony, zachowane jedynie fragmenty piramid kości skroniowych, kości jarzmowej, fragment trzonu prawej kości udowej, drobne ułamki łuków kręgów oraz żeber, 4 paliczki, bardzo drobne fragmenty trzonów nieokreślonych kości długich.

Nie odnotowano zmian patologicznych.

\section{Popielnica 36}

Szczątki kostne dziecka, zmarłego w wieku infans I (płód/zgon okołoporodowy).

Barwa kości kremowa, rozdrobnienie bardzo silne.

Ciężar szczątków: $38 \mathrm{~g}$.

Czaszka: zachowane jedynie fragmenty piramid kości skroniowych, ułamek kości jarzmowej. Zęby: korona górnego siekacza szczęki oraz 3 małe fragmenty koron zębowych.

Szkielet pozaczaszkowy: 3 fragmenty trzonów kości długich, drobne fragmenty kostne żeber i trzonów kości długich.

Nie stwierdzono zmian patologicznych.

\section{Popielnica 41}

Szczątki kostne dziecka w wieku infans I (płód, noworodek?).

Ciężar szczątków: $12 \mathrm{~g}$.

Materiał osteologiczny silnie rozdrobniony, barwa przepalenia szarobrunatna. Zachowane jedynie 2 fragmenty piramid kości skroniowych, 3 fragmenty trzonów kości długich oraz bardzo drobne ułamki kostne. 


\section{UWAGI KOŃCOWE}

Materiał osteologiczny w postaci przepalonych szczątków kostnych pochodził z grobu 1 odkrytego na cmentarzysku kultury pomorskiej w Kręcieszkach, gm. Bedlno. W grobie tym znajdowało się 36 popielnic, jednak tylko w 21 $\mathrm{z}$ nich stwierdzono szczątki kostne. Zwraca uwagę fakt, iż były to pochówki jednoosobowe (w żadnej z popielnic nie odnotowano szczątków dwóch lub większej liczby osób).

Analiza antropologiczna wykazała, iż materiał kostny pochodzący od 21 osób, w tym 11 dzieci w wieku infans I (poniżej 6 lat), 2 dzieci w wieku infans II (6-14 lat), 7 osób dorosłych oraz jednego osobnika, którego płci i wieku nie ustalono ze względu na niewielką ilość zachowanych fragmentów kostnych. Pochówki dziecięce stanowiły zatem najliczniejszą grupę (62\% ogółu). Wśród nich stwierdzono siedem wczesnych zgonów najprawdopodobniej w wyniku komplikacji okołoporodowych. W przypadku osób dorosłych płeć ustalono u 6 z 7. Popielnice o numerach 3, 10, 26 zawierały szczątki kostne mężczyzn, zaś popielnice 6, 11 i 19 szczątki kobiet. Zarówno mężczyźni jak i kobiety zmarli w kategorii wiekowej adultus/maturus oraz maturus.

Przyżyciową wysokość ciała ustalono u 5 osobników: 3 mężczyzn, 1 kobiety i 1 osobnika dorosłego o płci nieokreślonej. Analiza powyższej cechy wskazuje, iż nie była to społeczność niskorosła, gdyż wzrost przyżyciowy w przypadku dwóch mężczyzn określono na około $170 \mathrm{~cm}$ (popielnica $\mathrm{nr} 10$ ) i około $175 \mathrm{~cm}$ (popielnica nr 26), zaś kobiety na około $165 \mathrm{~cm}$.

Tylko w czterech przypadkach zaobserwowano zmiany patologiczne pozostawiające swój ślad na materiale kostnym. U jednej kobiety (popielnica nr 6) stwierdzono schorzenia aparatu żucia i osteofitozę widoczną na trzonach kręgów. Schorzeniem o innej etiologii, zaobserwowanym u dwójki dzieci (popielnice $\mathrm{nr} 13$ i 14) są zmiany przerostowe w stropie oczodołów (cribra orbitalia). Powstanie tych zmian przypisywane jest niedoborowi żelaza w organizmie i jest oznaką anemii. Przyczyną niedokrwistości obok niedostatku żelaza w diecie są również choroby genetyczne, zakażenia pasożytami czy też inne choroby zakaźne osłabiające organizm (Larsen 1997). 
Tabela 1. Zestawienie danych o pochówkach (dane własne).

\begin{tabular}{|c|c|c|c|c|c|}
\hline $\begin{array}{c}\mathrm{Nr} \\
\text { popielnicy }\end{array}$ & Pleć & $\begin{array}{l}\text { Wiek } \\
\text { (lata) }\end{array}$ & $\begin{array}{l}\text { Wysokość } \\
\text { ciala }(\mathrm{cm})\end{array}$ & Patologie & $\begin{array}{c}\text { Stopień } \\
\text { przepalenia }\end{array}$ \\
\hline 3 & M? & $21-35$ & $\begin{array}{l}\text { około } \\
161-165\end{array}$ & & średni \\
\hline 4 & $?$ & infans I & & & silny \\
\hline 6 & $\mathrm{~K}$ ? & $30-40$ & & $\begin{array}{l}\text { - schorzenia } \\
\text { aparatu żucia } \\
\text { - osteofitoza }\end{array}$ & średni \\
\hline 7 & $?$ & infans I & & & silny \\
\hline 9 & $?$ & $20-35$ & $\begin{array}{c}\text { około } \\
160-164\end{array}$ & $\begin{array}{l}\text { - poroza } \\
\text { tk. kostnej }\end{array}$ & dość słaby \\
\hline 10 & M & $30-45$ & około 170 & & średni \\
\hline 11 & $\mathrm{~K}$ & $30-45$ & & & średni \\
\hline 13 & $?$ & infans II (12-14 lat) & & $\begin{array}{l}\text { - cribra } \\
\text { orbitalia }\end{array}$ & średni \\
\hline 14 & $?$ & infans I (około 4 lat) & & $\begin{array}{l}\text { - cribra } \\
\text { orbitalia }\end{array}$ & silny \\
\hline 15 & $?$ & infans I & & & silny \\
\hline 16 & $?$ & infans I (płód) & & & silny \\
\hline 19 & $\mathrm{~K}$ & $30-35$ & około 165 & & średni \\
\hline 21 & $?$ & infans I (płód) & & & silny \\
\hline 24 & $?$ & infans I (3-4 lata) & & & silny \\
\hline 25 & $?$ & infans II (około 12 lat) & & & dość silny \\
\hline 26 & $\mathrm{M}$ & $30-55$ & około 175 & & średni \\
\hline 27 & $?$ & $?$ & & & silny \\
\hline 28 & $?$ & infans I (5-6 lat) & & & silny \\
\hline 34 & $?$ & $\begin{array}{c}\text { infans I } \\
\text { (około 6-9 mies.) }\end{array}$ & & & silny \\
\hline 36 & $?$ & $\begin{array}{c}\text { infans I } \\
\text { (płód/noworodek) }\end{array}$ & & & silny \\
\hline 41 & $?$ & $\begin{array}{c}\text { infans I } \\
\text { (płód/noworodek) }\end{array}$ & & & silny \\
\hline
\end{tabular}

M - mężczyzna, $\mathrm{K}$ - kobieta 
Beata Borowska-Strugińska

Katedra Antropologii

Uniwersytet Łódzki

ul. Banacha 12/16

90-237 Łódź

e-mail: beata.borowska@biol.uni.lodz.pl

Mariusz Rychter

Instytut Archeologii

Uniwersytet Łódzki

ul. Narutowicza 65

90-131 Łódź

e-mail: mariusz.rychter@uni.lodz.pl

\section{Bibliografia}

Gładykowska-Rzecycka J.J. (1976), Badania populacji ludzkich na materiałach wspótczesnych i historycznych, Wydawnictwo Naukowe, Poznań.

Gładykowska-Rzeczycka J.J. (1989), Schorzenia ludności prahistorycznej na ziemiach Polski, Wydawnictwo Muzeum Archeologicznego, Gdańsk.

Kondracki J. (1981), Geografia fizyczna Polski, Państwowe Wydawnictwo Naukowe, Warszawa.

Larsen C.S. (1997), Bioarchaeology, Cambridge University Press, Cambridge.

Malinowski A., Strzałko J. (1985), Antropologia, Państwowe Wydawnictwo Naukowe, Warszawa-Poznań.

Malinowski A., Wolański N. (1988), Metody badań w biologii człowieka, Państwowe Wydawnictwo Naukowe, Warszawa.

Rychter M. (2010), Elementy konstrukcyjne domu ,ryglowego” z okresu wplywów rzymskich odkrytego na stanowisku $n r 1$ w Kręcieszkach, [w:] A. Urbaniak, R. Prochowicz, I. Jakubczyk, M. Levada, J. Schuster (red.), Terra Barbarica. Studia ofiarowane Magdalenie Maczyńskiej w 65. rocznicę urodzin (= Monumenta Archaeologica Barbarica. Series Gemina t. 2), Instytut Archeologii Uniwersytetu Łódzkiego, Fundacja Uniwersytetu Łódzkiego, Fundacja Monumenta Archaeologica Barbarica, Państwowe Muzeum Archeologiczne w Warszawie, Łódź-Warszawa, s. 745-754.

Rychter M., Stasiak S. (2006-2007), Cmentarzysko ludności kultury pomorskiej w Kręcieszkach gm. Bedlno, pow. Kutno, woj. łódzkie, „Łódzkie Sprawozdania Archeologiczne", t. X, s. 27-71.

Strzałko J., Henneberg M. (1975), Określenie ptci na podstawie morfologii szkieletu, „Przegląd Antropologiczny”, t. 41, z. 1, s. 150-126.

Strzałko J., Piontek J., Malinowski A. (1974), Możliwości identyfikacji szczątków ludzkich z grobów ciałopalnych $w$ świetle badań eksperymentalnych, [w:] H. Giżyńska (red.), Materiały z konferencji, Metody, wyniki i konsekwencje badań kości z grobów ciałopalnych, Wydawnictwo Uniwersytetu Adama Mickiewicza, Poznań, s. 31-42. 
SUMmary

ANTHROPOLOGICAL ANALYSIS OF SKELETAL REMAINS FROM A BOUGHT CONNECTION CENTER OF POMERANIAN CULTURE FROM STAND NO. 1 IN KRECESZKI, GM. BEDLNO, POW. KUTNO, WOJ. LODZKIE

During the rescue research carried out in 1987, a box grave of Pomeranian culture dating back to the Hallstatt D.

Found in it, in addition to numerous attachments and lids 36 large vessels, including 23 typical, referred to as urns. Bone remains were preserved only in 21 vessels. Anthropological analysis has shown that human bones come from 21 people, that is, 11 children (under 6 years), 2 children in infans II age (6-14 years), 7 adults ( 3 men, 3 women and one adult). Only in four cases, lesions were observed. 